\title{
Two-dimensional numerical modeling of flood wave propagation in an urban area due to Ürkmez dam-break, İzmir, Turkey
}

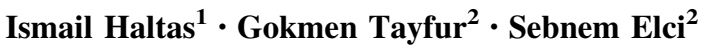

Received: 13 March 2015/Accepted: 18 January 2016/Published online: 2 February 2016

(C) Springer Science+Business Media Dordrecht 2016

\begin{abstract}
This study investigated flood inundation in an urban area due to a possible failure of Ürkmez Dam in İzmir, Turkey. The estimation of flood hydrograph upon partial failure of the dam and routing of the flood hydrograph along the narrow valley downstream were first performed by the one-dimensional hydraulic routing model HEC-RAS. The twodimensional hydraulic routing model FLO-2D is then used to simulate the spreading of the dam-break flood after the flood wave exits the valley. Land use and land cover digital maps were utilized to find the spatially varying roughness coefficient for the floodplain. The influence of the buildings on the flood propagation was represented in the numerical model by the area reduction factor as well as the width reduction factor. The peak flow depth, peak flow velocity and time moment of the peak flow depth maps were shown in the GIS environment. The results reveal that flow depths can reach about $3 \mathrm{~m}$ in the residential area. In about 40 min after the dam-break, houses in the large section of the town would be under the maximum flow depths. The two-dimensional hydrodynamic model results were tested against experimental dam-break flow data of the distorted physical model of Ürkmez Dam, which is consisted of the reservoir, dam body and downstream area including Ürkmez Town. The model successfully simulated experimental flow depth data measured at different measurement locations.
\end{abstract}

Keywords Dam-break inundation - GIS integrated inundation mapping - FLO-2D - HECRAS · Ürkmez Dam, numerical simulation

Gokmen Tayfur

gokmentayfur@iyte.edu.tr

Ismail Haltas

ihaltas@gmail.com

Sebnem Elci

sebnemelci@iyte.edu.tr

1 Department of Civil Engineering, Zirve University, Gaziantep, Turkey

2 Department of Civil Engineering, Izmir Institute of Technology, Izmir, Turkey 


\section{Introduction}

Floods caused by sudden releases of water from dam failures may cause serious damage to life and property. Dam failure may mainly occur as a result of insufficient spillway, slope failure, structural deficiency, seepage and piping, earthquake, etc. (Yanmaz and Beser 2005). According to International Commission on Large Dams, ICOLD, in 1973, $38 \%$ of the failures are due to insufficient spillway design, whereas $33 \%$ of the failures are due to seepage and piping that are very important problems in earth fill dams. Although it is rare, there have been dam failures around the world such as concrete St. Francis Dam in USA, Vajont Dam in Italy and Teton Dam in USA. Recently, on March 26, 2009, an earth fill dam in Indonesia failed and caused lives of more than 100 people and buried hundreds of homes. According to Wikipedia source (http://en.wikipedia.org/wiki/Dam_failure), 18 dams failed between 1900 and 1970, 17 between 1970 and 2000 and 25 after 2000. Additional information about dam failures can be found in the Centre for the Assessment of Natural Hazards and Proactive Planning (CANAH) of the National Technical University of Athens (http://naturalhazards.ntua.gr/).

Both dam-break and flood wave propagation have been experimentally studied in the literature by several researchers (Vasquez and Leal 2006; Minussi and Maciel 2008; Çagatay and Kocaman 2008; Palumbo et al. 2008; Morris et al. 2008; Kocaman and Çagatay 2009). These studies mainly focused on definition of flow characteristics at the time of failure, the failure mechanism and flood wave propagation, using idealized and oversimplified physical models. Most recently, Guney et al. (2014) carried out dam-break flow experiments in a distorted physical model of Ürkmez Dam, which consisted of dam reservoir, dam body and downstream area including Ürkmez Town. The constructed physical model included topographic details in the floodplain such as elevated roads, streambeds and buildings as well. In their study, they presented the construction of the physical model, instrumentation and measurements, and analysis of experimental data.

There have been also numerical modeling studies of flood wave propagation in floodplain mostly in one dimension ( $\mathrm{Li}$ et al. 1991; Bellos and Hrissanthou 1998; Yanmaz et al. 2001; Bozkus 2003; Macchione 2008; Petaccia et al. 2008; Froehlich 2008; Bozkus 2009; Tsakiris and Spilliotis 2013; Bosa and Petti 2013) and few in two dimensions (Brufau et al. 2002; Ying et al. 2009; Singh et al. 2011; Qi and Altinakar 2012; Mahdizadeh et al. 2012). Alcrudo and Mulet (2007), Pilotti et al. (2011), and Moramarco et al. (2014) simulated historical dam-break flows, predicting inundated areas using data on geometric properties of dam, land use and topography. Some studies attempted to model hypothetical dam-break scenario for existing dams with topographic and land use data and geometric properties of dam and reservoir (Bozkus and Guner 2001; Bozkus and Bag 2011; Haltas and Odell 2013).

Recently, Bellos and Tsakiris (2015) discussed how to represent roughness effects of buildings in urban areas subject to flooding by carrying out numerical simulations. They tested the performance of their model against three different representations under three different flood hydrographs. Their numerical test analysis results revealed that the reflection boundary method better replicates the resistance caused by buildings. Pinho et al. (2015) compared two different hydrodynamic models for flood simulations of historical events in River Lima Basin in Portugal. According to their results, the inundation model based on the unstructured mesh reveals more computational efficiency when high resolution is required. Also, they suggest the use of the finite element mesh instead of a grid for two-dimensional inundation simulations. 
Flood wave propagation resulting from a hypothetical failure scenario for Ürkmez Dam in İzmir, Turkey, was numerically modeled in this study. The simulation involved two phases: (1) the estimation of flood hydrograph upon failure of the dam (USACE 2014) and routing of the flood hydrograph along the narrow valley downstream were performed by the one-dimensional hydraulic routing model, HEC-RAS, developed by the US Army Corps of Engineers (USACE 2010). HEC-RAS is a widely used one-dimensional hydrodynamic model in river hydraulics as well as dam-break analysis (USACE 2014). In the dam-break analysis with HEC-RAS, dams are modeled as inline structures in a river reach. In this study the dam reservoir, dam and 300-m-long reach of creek downstream of the dam are modeled in HEC-RAS. At the downstream of the dam, there is an approximately 300-m-long valley where the flood wave is confined and the one-dimensional flow assumptions are acceptable. (2) In this phase, the two-dimensional spreading of the flood wave on floodplain after it exits the valley was modeled using the two-dimensional hydraulic routing model, FLO-2D (2009a). FLO-2D is also a widely accepted finite difference method-based two-dimensional hydrodynamic routing model. There are numerous dam-break flood-modeling studies (Haltas and Odell 2013; GEI 2014) in the literature using FLO-2D. The two-dimensional hydrodynamic model results of the hypothetical dambreak scenario were analyzed in GIS, and the peak inundation depth, peak velocity and time moment of the peak inundation depth maps were prepared for the floodplain downstream of Ürkmez Dam. The two-dimensional numerical model results were also tested against the experimental data from the distorted physical model (Guney et al. 2014), which replicates the body and reservoir of Ürkmez Dam, and the downstream area including Ürkmez Town.

\section{Numerical model}

\subsection{First phase: modeling dam-break using HEC-RAS}

The one-dimensional hydraulic model consisting of Ürkmez Reservoir, Ürkmez Dam, and the Ürkmez Creek downstream of the dam was set up for the calculation of the dam-break

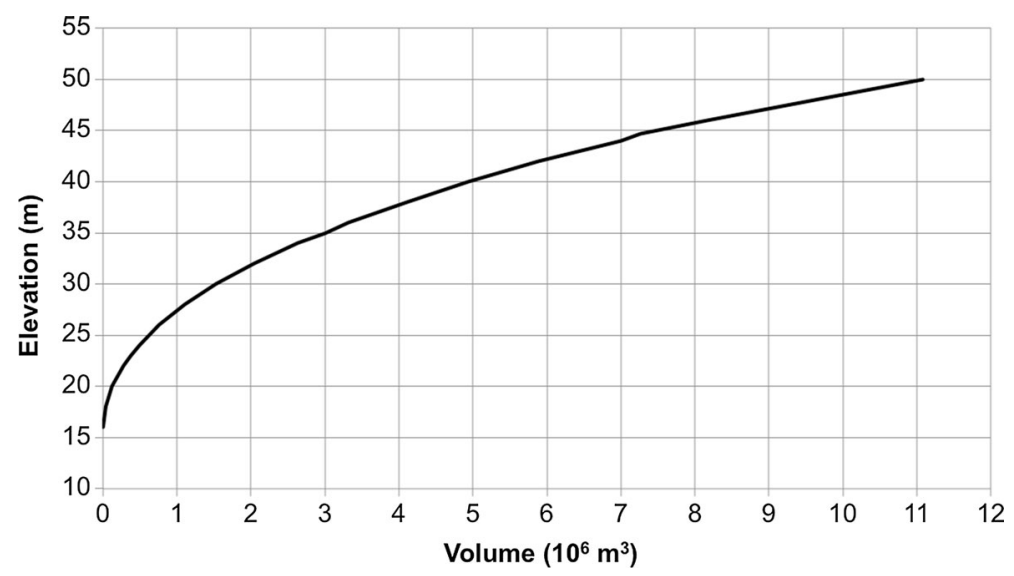

Fig. 1 Elevation-storage curve of the Ürkmez reservoir 
flood hydrograph for the hypothetical dam-break scenario. In this hypothetical dam-break scenario, overtopping type of failure is assumed. The water surface elevation of the reservoir at the time of failure is assumed to be at crest elevation that is $44.88 \mathrm{~m}$. The water surface elevation of the reservoir and the elevation-storage curve of the reservoir set the upstream boundary of the model. The elevation-storage curve (Fig. 1) of the reservoir was utilized as upstream boundary condition for the weir flow module that is used to model the dam-break process.

The geometry of the dam body and the elevation-storage curve of the reservoir were obtained from the feasibility report for the Ürkmez Dam (DSI 1979). Parameters used in the simulation of dam-break process by this module are calculated based on Froehlich equations (Froehlich 2008). Ürkmez Dam is an earthen embankment dam. For overtopping failure of earthen dams, the Froehlich equations are given as follows:

$$
B_{\text {ave }}=0.27 K_{0} V_{\mathrm{w}}^{0.32} h_{\mathrm{b}}^{0.04} \quad t_{\mathrm{f}}=0.0176 \sqrt{\frac{V_{\mathrm{w}}}{g h_{\mathrm{b}}^{2}}}
$$

where $B_{\text {ave }}=$ average breach width $(\mathrm{m}), t_{\mathrm{f}}=$ breach formation time $(\mathrm{h}), V_{\mathrm{w}}=$ reservoir volume at time of failure $\left(\mathrm{m}^{3}\right), h_{\mathrm{b}}=$ height of the final breach $(\mathrm{m}), K_{0}=$ constant $(1.3 \mathrm{for}$ overtopping failures) and $g=$ gravitational acceleration.

The average breach side slopes are given as $1 \mathrm{H}: 1 \mathrm{~V}$ for overtopping failures. The breach height $h_{b}$ is calculated as the height from the crest of the dam to the natural ground at the breach location. A typical value of 2.6 is used as weir discharge coefficient. The dam-break parameters are listed in Table 1.

In HEC-RAS, cross sections perpendicular to anticipated flow lines must be defined at locations where changes occur in discharge, slope, shape or roughness and at locations where levees begin or end and at bridges or control structures such as weirs (USACE 2010). Ürkmez Stream was divided by five cross sections placed approximately $50 \mathrm{~m}$ apart at the downstream of the dam, and one-dimensional flood routing was performed at these cross sections for approximately $300 \mathrm{~m}$ of the stream (Fig. 2). The surface-elevation data of these cross sections were extracted from 1-m resolution digital elevation model obtained from the topographic maps.

The normal depth of the most downstream cross section (XS 70) having a slope of $S=0.018$ was considered as the initial boundary condition. The unsteady flow simulation and the dam failure were started at 00:00. The flow hydrograph calculated at the cross section (XS 144) located immediately upstream of the downstream boundary cross section was used as the dam-break hydrograph for the two-dimensional model. Figure 3 shows the calculated flood hydrograph reaching its peak value of $6417 \mathrm{~m}^{3} / \mathrm{s}$ at 00:32 a.m. and experiencing total attenuation at 01:00 a.m. The calculated flood hydrograph was set as the

Table 1 HEC-RAS hypothetical failure dam-break parameters for Ürkmez Dam

\begin{tabular}{ll}
\hline Parameters & Value \\
\hline Crest height & $45.88 \mathrm{~m}$ \\
Final bottom elevation & $17 \mathrm{~m}$ \\
Height of the final breach & $26.9 \mathrm{~m}$ \\
Reservoir volume & $7.6 \times 10^{6} \mathrm{~m}^{3}$ \\
Average breach width & $63.7 \mathrm{~m}$ \\
Final bottom width & $36.8 \mathrm{~m}$ \\
Breach formation time & $0.57 \mathrm{~h}$ \\
\hline
\end{tabular}




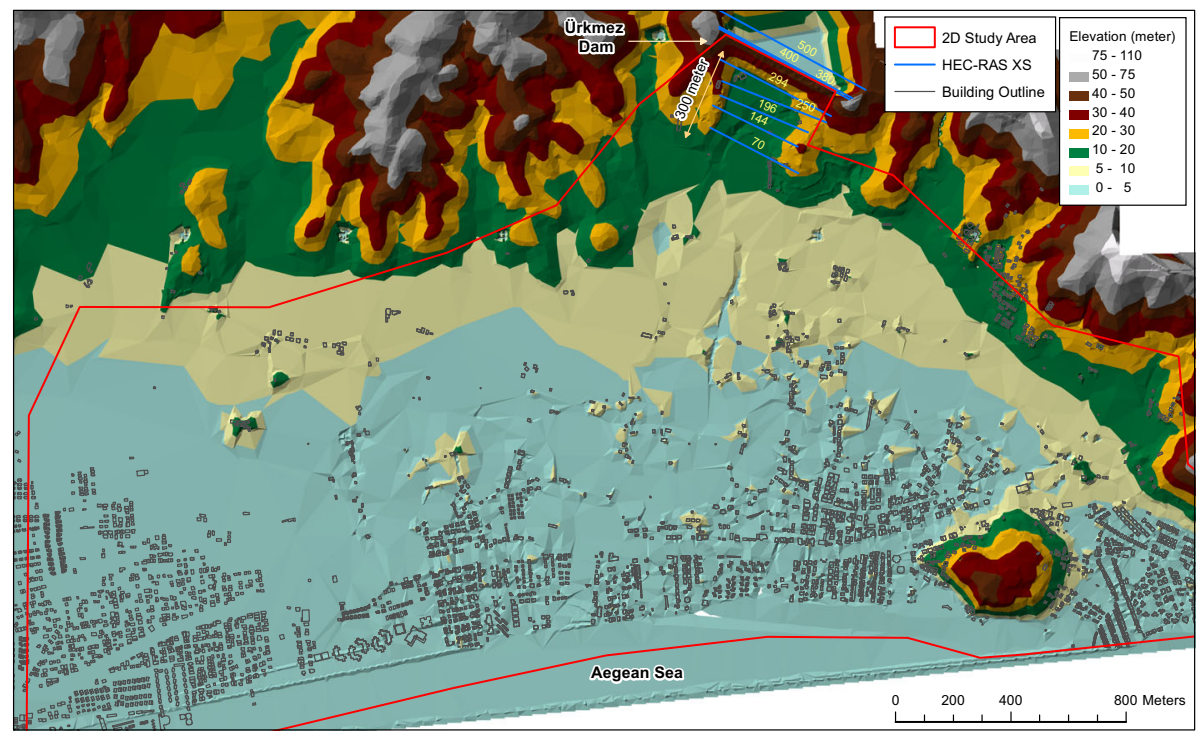

Fig. 2 Topography of the study area, 2D model boundary, buildings outline and the 1D model cross-section locations

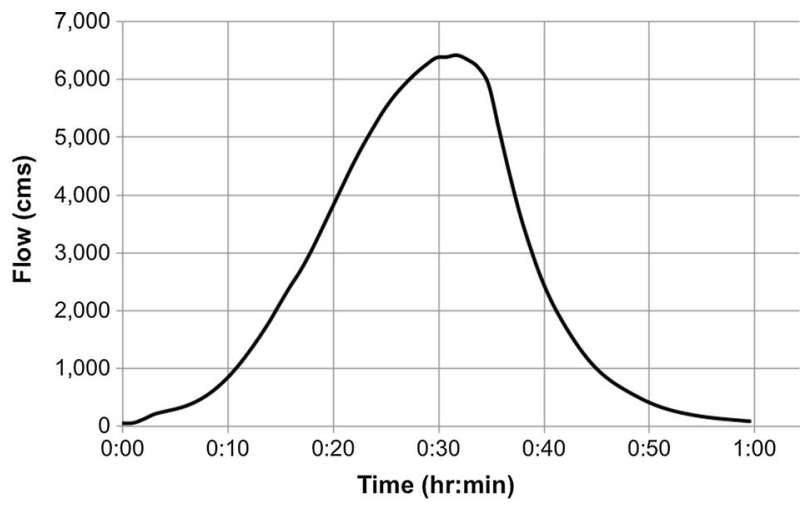

Fig. 3 Calculated flood hydrograph by HEC-RAS at cross section XS 144 for the hypothetical dam-break scenario

inflow hydrograph in the two-dimensional hydrodynamic model at the second phase of the numerical modeling.

\subsection{Second phase: modeling flood wave spreading using FLO-2D model}

Once flow enters the valley, the two-dimensional spreading of the flood wave over Ürkmez Creek and the floodplain is modeled using FLO-2D, which is a physical process model that routes flood hydrographs over unconfined flow surfaces or in channels. It is a simple volume conservation model and has a number of components to simulate street flow, buildings and obstructions, sediment transport, spatially variable rainfall and infiltration, 
floodways and many other flooding details. The unsteady flow equations in two dimensions also solved by the FLO-2D model can be expressed as follows (Ying et al. 2009):

$$
\frac{\partial U}{\partial t}+\frac{\partial F}{\partial x}+\frac{\partial G}{\partial y}=S
$$

where,

$$
U=\left[\begin{array}{l}
h \\
h u \\
h v
\end{array}\right] \quad F=\left[\begin{array}{l}
h u \\
h u u \\
h u v
\end{array}\right] \quad G=\left[\begin{array}{l}
h v \\
h u v \\
h v v
\end{array}\right] \quad S=\left[\begin{array}{l}
0 \\
-g h \frac{\partial Z}{\partial x}-g \frac{n^{2} u \sqrt{u^{2}+v^{2}}}{h^{1 / 3}} \\
-g h \frac{\partial Z}{\partial y}-g \frac{n^{2} u \sqrt{u^{2}+v^{2}}}{h^{1 / 3}}
\end{array}\right]
$$

where $h$ is flow depth, $u$ is velocity in $x$-direction, $v$ is velocity in $y$-direction, $g$ is gravitational acceleration, $Z$ is water surface elevation and $n$ is Manning's roughness coefficient.

The differential form of the continuity and momentum equations in the model is solved by an explicit central finite difference numerical scheme. Courant-Friedrich-Lewy condition is used as numerical stability criteria. To meet the stability criteria, variable time steps are used (FLO-2D 2009b).

\subsubsection{Specification of model domain and grid size of elements}

Topography of the study area at a scale of 1/5000 was obtained from the National Mapping Agency of Turkey and concerted to a digital elevation model (DEM) raster with a resolution of $1 \mathrm{~m}$ using GIS software. The soil and vegetation maps having a scale of 1/25,000 were obtained from the Ministry of Food, Agriculture and Husbandry. The digital elevation model was edited to embed the dam body and the streambed on the model. The twodimensional model boundary is determined based on the topography. Then the computational grid is created. It is recommended to maintain balance between the number of grid elements and an acceptable computational time, and hence a grid size ranging between 15 and $150 \mathrm{~m}$ is usually appropriate for most simulations (FLO-2D 2009a). The following criterion was suggested (FLO-2D 2009b) and used in the selection of the grid size:

$$
0.3 \mathrm{~m} / \mathrm{s} \leq Q_{\max } / A_{\text {elem }} \leq 3 \mathrm{~m} / \mathrm{s}
$$

where $Q_{\max }$ is the maximum discharge estimated at the grid element and $A_{\text {elem }}$ is the grid area. Based on this criterion, the grid size was set as $25 \mathrm{~m}$ by $25 \mathrm{~m}$.

\subsubsection{Specification of elevation, roughness and area reduction factor for grid elements}

The 1-m resolution digital elevation model was used to calculate the elevation of each grid element. In addition, the land use and land cover digital maps were utilized to find the spatially varying roughness coefficient for the floodplain. Using the $1 / 1000$-scale city development maps of Ürkmez region, obtained from İzmir Municipality Department, the obstruction (buildings) map of the floodplain were constructed as polygon layer. Within the study area, 5096 buildings covering about $428,640 \mathrm{~m}^{2}$ of area are identified as residential and another 128 buildings covering $31,459 \mathrm{~m}^{2}$ of area used for other purposes. Figure 2 
shows the topography for the region, the two-dimensional model study area and the building outlines.

The influence of the buildings on the flood propagation was modeled in the twodimensional hydrodynamic model by area reduction factor (ARF) as well as width reduction factor (WRF). The ARF is a parameter that accounts for what percentage of a computational cell is occupied by a structure (FLO-2D 2009a, b). The ARF parameter is used in the mass conservation equation in the numerical scheme. It is set to 0 if there is no building (obstruction) in a cell and it is set to 1 if the cell is completely occupied by a building. In the numerical scheme of the FLO-2D, each grid element can share discharge in eight directions. The grid element can be considered to be an octagon, and each WRF factor refers to the percent blockage of one of the eight sides (FLO-2D 2009b). Figure 4 shows some typical ARF values in the study area calculated using the buildings polygon layer.

\subsubsection{Specification of inflow and outflow grid elements}

In the two-dimensional model, the calculated dam-break flood hydrograph was distributed over eight adjacent grid elements along the cross section XS 144, resulting in the maximum discharge for each element being $Q_{\max }=802 \mathrm{~m}^{3} / \mathrm{s}$ and satisfying the condition of $Q_{\max } / A_{\text {elem }}=1.3 \mathrm{~m} / \mathrm{s} \leq 3 \mathrm{~m} / \mathrm{s}$.

The dam-break floodwater was expected to drain to the sea over the road along the south border of the study area at critical depth, which is the downstream boundary condition. Therefore, outflow grid elements with critical depth conditions were defined along the south border.

In the study area, there are totally 9814 grid cells, of which 5830 became wet during the simulation. The 2-h-long simulation took $4.48 \mathrm{CPU}$ hours at Intel Core i5 @3.26 Hz processor.

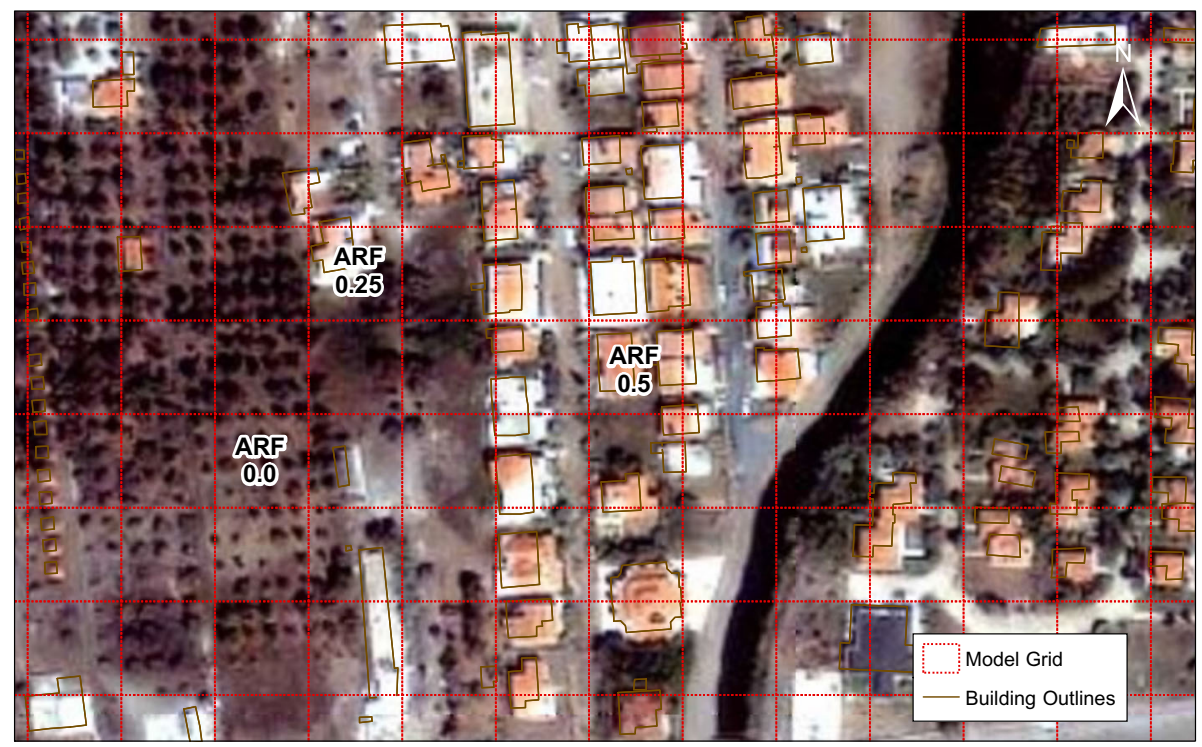

Fig. 4 Typical ARF values for some computational cells 


\section{Flood hazard mapping}

The MAPPER which is the post-processing component of FLO-2D was utilized to create the flood hazard map layers as shapefiles based on the two-dimensional hydrodynamic model results for the hypothetical dam-break scenario. Based on the numerical model results, maximum flow depth, maximum resultant flow velocity and time to maximum flow depth maps are created.

The maximum flow depth map is presented in Fig. 5. Flow depths reach up to $3 \mathrm{~m}$ in the residential area. The maximum resultant flow velocity map is presented in Fig. 6. Flow velocities become as high as $15 \mathrm{~m} / \mathrm{s}$ just downstream of the dam, and the flow slows down to about $2-5 \mathrm{~m} / \mathrm{s}$ in the residential area. The time to maximum flow depth map is presented in Fig. 7. It is shown that within 40 min after the dam starts to fail, most of the residential area in Ürkmez Town will be flooded at the maximum flow depths.

\section{Numerical model testing against experimental data}

The performance of the two-dimensional numerical model was tested by comparing the numerically calculated flow depth hydrographs with the flow depth hydrographs measured in the downstream area of the distorted physical model of Ürkmez Dam in Guney et al. (2014).

\subsection{Physical model and flow depth measurements}

The distorted physical model of Ürkmez Dam in İzmir, Turkey, was built to study sudden dam-break flows. The distorted model had a horizontal scale of $1 / 150$ and a vertical scale of $1 / 30$, containing dam reservoir, dam body and the floodplain until the coastline of the

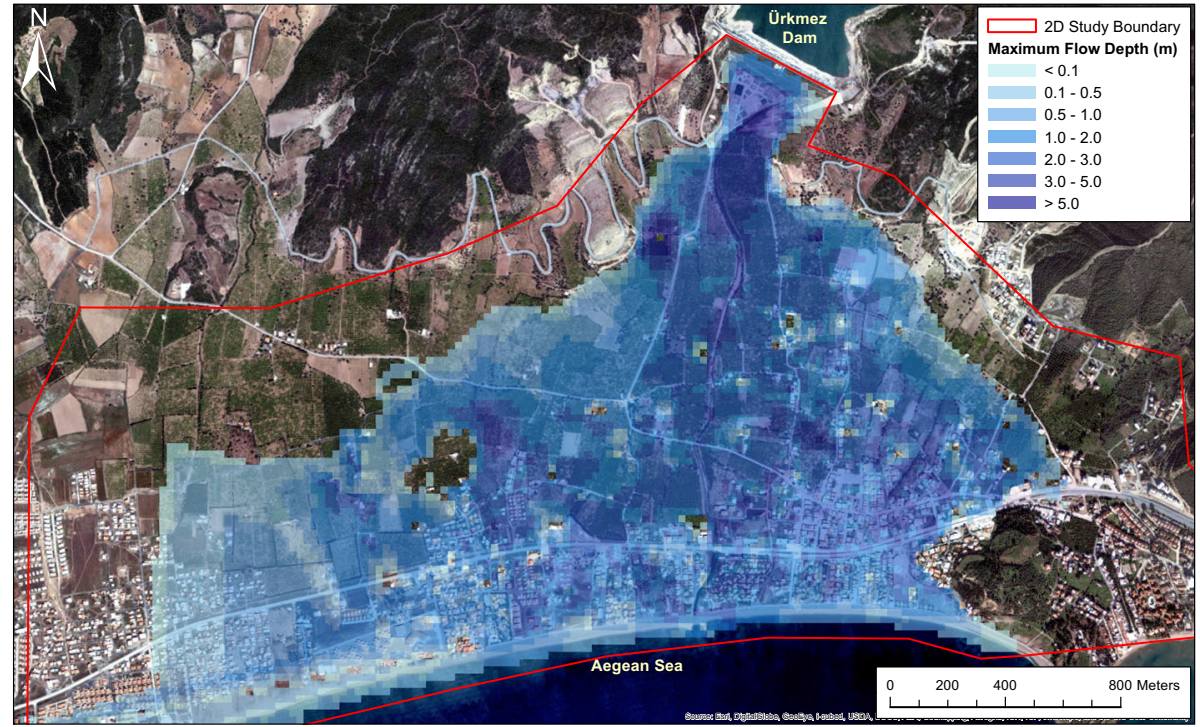

Fig. 5 Maximum flow depth map 


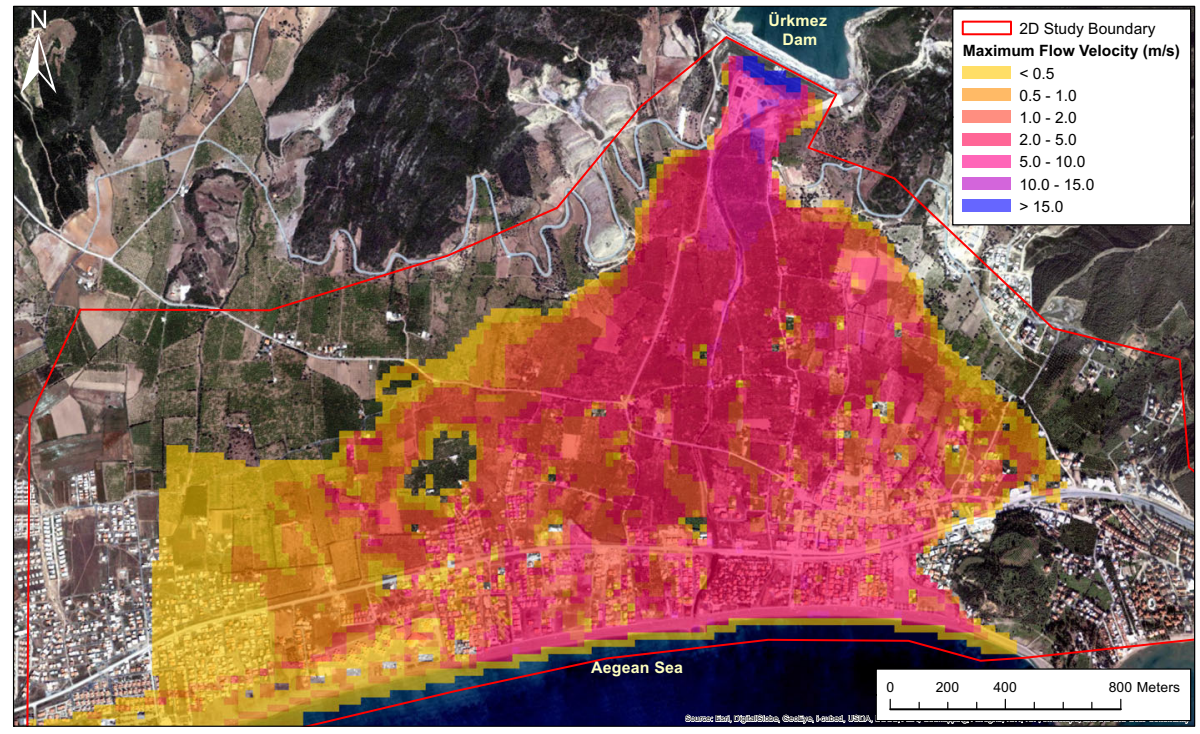

Fig. 6 Maximum flow velocity map

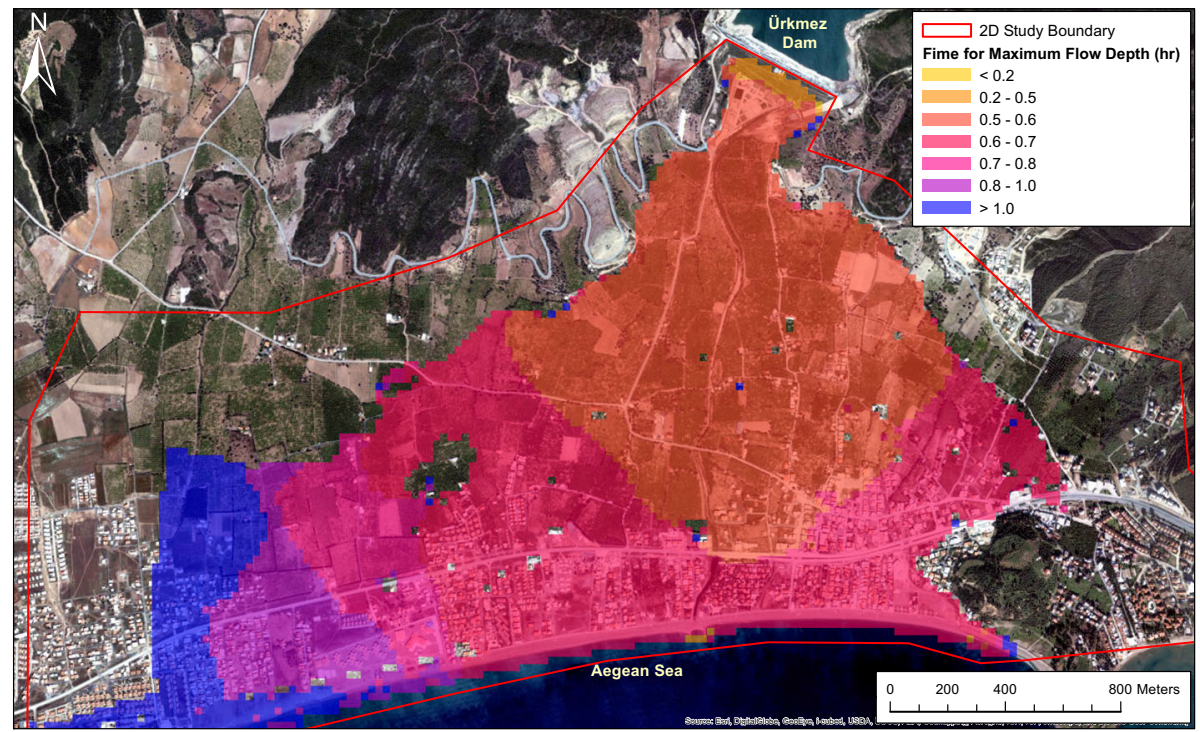

Fig. 7 Maximum flow depth arrival time map

Aegean Sea. In the physical model, the reservoir capacity is approximately $12 \mathrm{~m}^{3}$, the dam body has a width of $2.84 \mathrm{~m}$ and a height of $1.07 \mathrm{~m}$ and the floodplain area is nearly $200 \mathrm{~m}^{2}$.

The features affecting the flood propagation such as buildings, bridge and elevated roads were also reflected in the physical model. The dam-break flow was investigated for 
sudden collapse, which was simulated by a trapezoidal breach on the dam body. Figure 8 shows a picture from the distorted physical model. The water depths at downstream area were measured at eight different locations by using e+ WATER L (level) sensors. Figure 9 shows a picture of the level sensors on the physical model, and Fig. 10 shows the locations of the level sensors on the map. The details on the physical model and experiments can be found in Guney et al. $(2013,2014)$.

\subsection{Two-dimensional numerical model}

In this numerical model testing, a prototype-scale two-dimensional numerical model of the study area is prepared in order to test the numerical simulation results with the physical model results. As apposed to the two-dimensional numerical model that is used for flood mapping (Sect. 2.2), in this testing case, the numerical model is prepared with the hydraulic conditions consistent with the physical model. Also, in this numerical model testing, the dam-break flood hydrograph measured in the physical model is used as apposed to the dam-break hydrograph calculated by the one-dimensional HEC-RAS model. The dam-break flood hydrograph from the physical model experiment is calculated by measuring the water level in the reservoir (L1) and converting the measured water levels to discharges by using the elevation-storage curve of the model reservoir. The calculated dam-break flood hydrograph is then scaled (the scale is Froude scale) back to the prototype scale from the model scale and used as the inflow hydrograph in the two-dimensional FLO2D model.

Also, the two-dimensional numerical model resolution is set to $75 \mathrm{~m}(0.5 \mathrm{~m}$ in the model scale) to be consistent with the as-built topography precision in the physical model. A constant Manning's roughness coefficient of 0.04 is used to represent the uniform roughness of the unfinished concrete surface of the floodplain in the physical model after a calibration process. For the calibration of the Manning's roughness coefficient $(n)$, two different uniform roughness values of 0.02 and 0.04 are tested and the flow depth hydrographs at locations L10 and L11 (see Fig. 9) are compared with the measured flow depths. The hydrograph simulation at L10 produced $R^{2}=0.965$ and MAE (mean absolute error) of $0.119 \mathrm{~m}$ for the case of $n=0.04$, and $R^{2}=0.845$ and MAE of $0.234 \mathrm{~m}$ for the case of $n=0.02$. The hydrograph simulation at L11 produced $R^{2}=0.965$ and MAE of

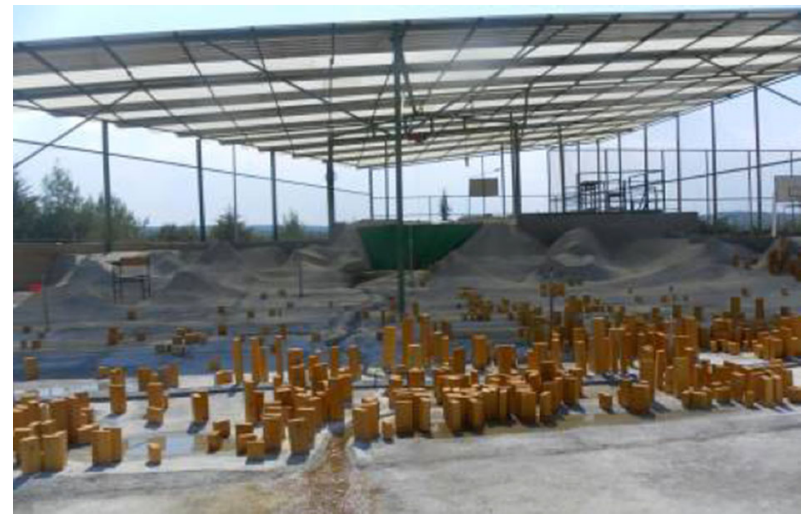

Fig. 8 View of the roof and the final version of the constructed distorted physical model 


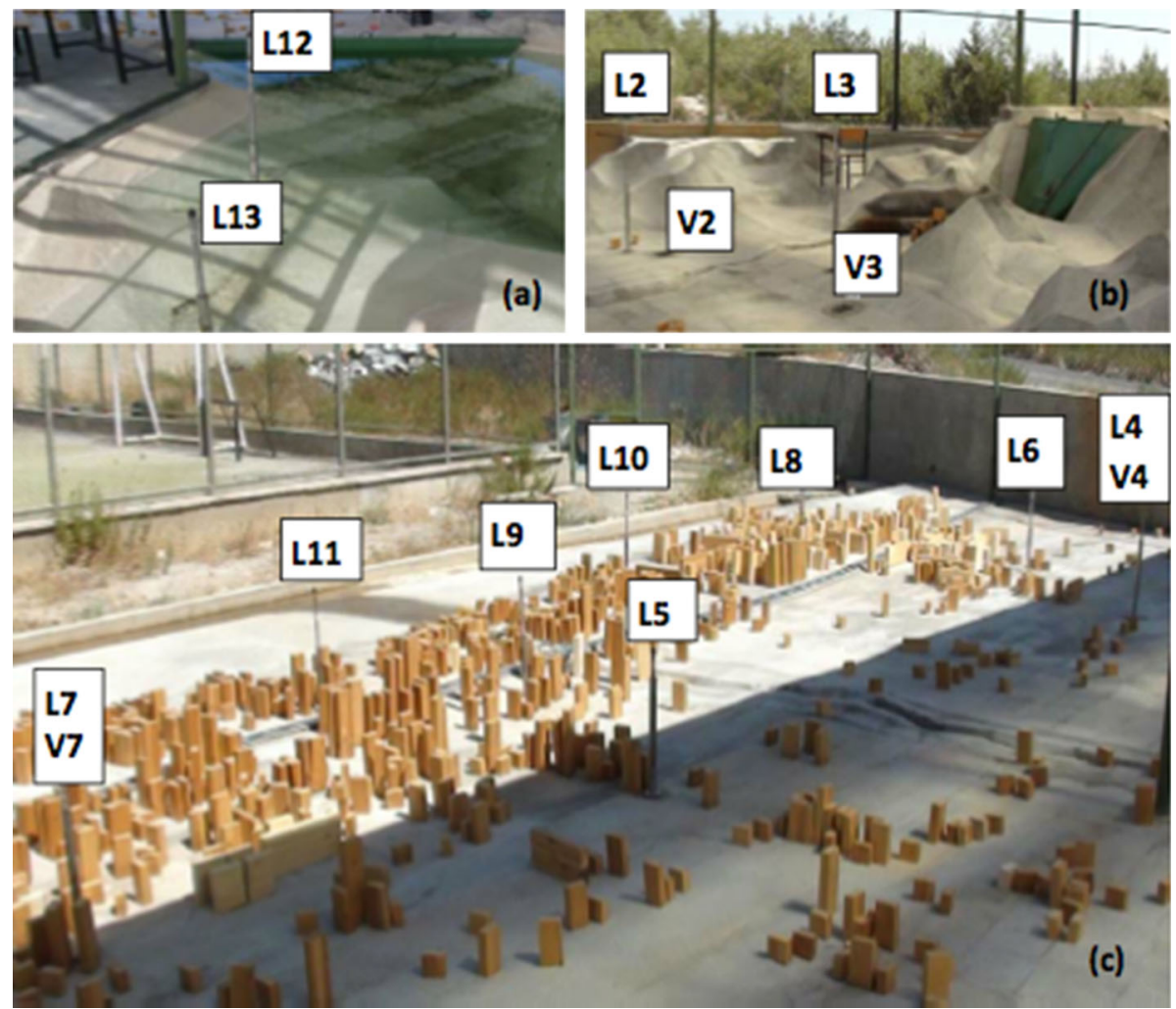

Fig. 9 Locations of level meters a dam reservoir ( $L 1$ is just behind $L 12$ ), b downstream part of the dam and c the residential area

$0.109 \mathrm{~m}$ for the case of $n=0.04$, and $R^{2}=0.874$ and MAE of $0.371 \mathrm{~m}$ for the case of $n=0.02$. Hence, $n=0.04$ is employed for the simulation of hydrographs at other locations.

The buildings and obstructions in the physical model are also counted in the numerical model by spatially varying area reduction factor (ARF) as well as width reduction factor (WRF). In this numerical model testing, there were totally 1069 grid elements, of which 505 became wet during the simulation. The 2-h-long simulation took $0.12 \mathrm{CPU}$ hours at Intel Core i5 @ $3.26 \mathrm{~Hz}$ processor.

\subsection{Comparison of results}

Figures 11, 12 and 13 show the comparison of measured and calculated water depth at three measurement locations (L2, L7 and L9). For the sake of brevity, other five water depth comparisons were not provided graphically, yet the model performance as percent errors are summarized in Table 2 for all the comparison locations. Note that the measured flow depths were scaled back to the corresponding values at prototype scale by using the vertical scale of $1 / 30$ before being displayed in Figs. 11, 12 and 13. As seen in the graphical comparisons, the two-dimensional numerical model satisfactorily simulated temporal variations of flow depths at different locations in the floodplain. 


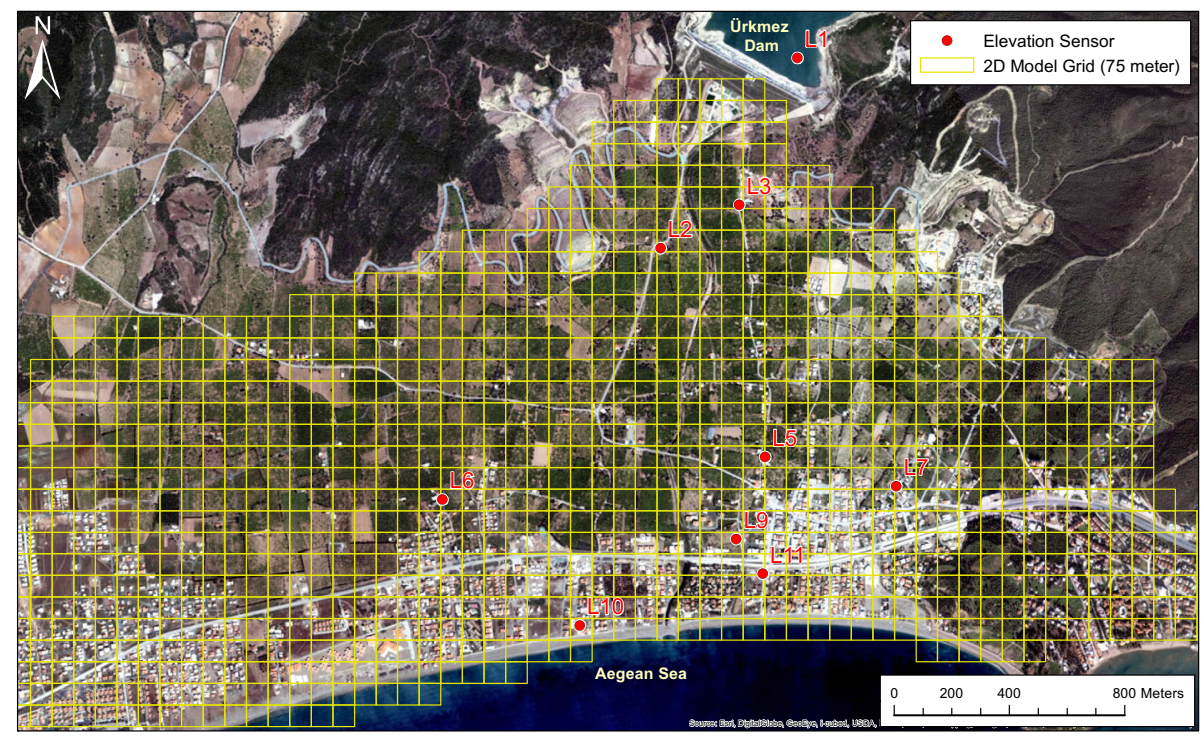

Fig. 10 Flow depth measurement locations on the map

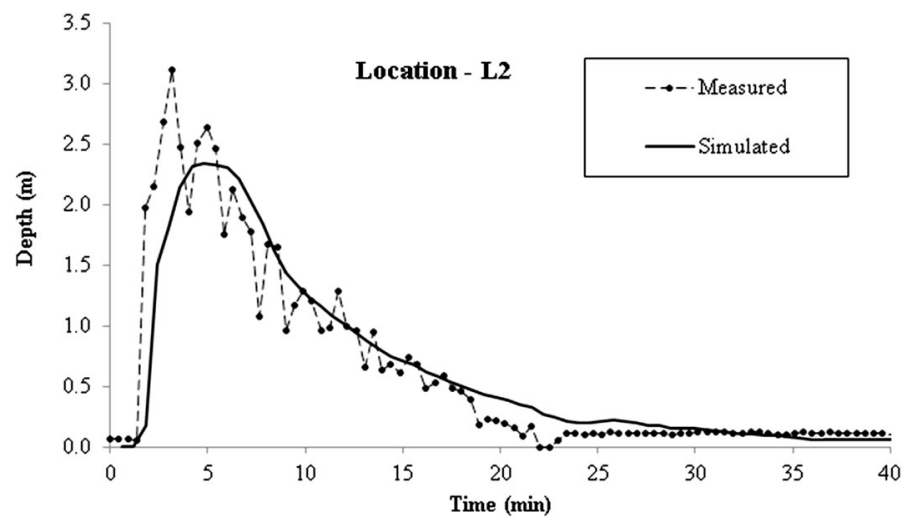

Fig. 11 Simulation of water level at L2

Figure 11 shows that the measured water levels fluctuate and the numerical model makes underestimation in L2 location. L2 level (water depth) measurement sensor is located just downstream of the dam body. During the physical model tests, it is observed that the fluctuations and splashes on the water surface is most pronounced near the immediate downstream of the dam during the lifting of the dam body. These fluctuations are also prominent in L2 water depth measurements shown in Fig. 9. 1:5 distortion in the horizontal and vertical scales also contributes to the magnitude of this noise in the measurements. The 2D numerical model is not capable of modeling the noise due to the splashes and disconnections in the water body, rather calculates relatively smooth varying (mean) water depths at the same location. Therefore, the numerically simulated water depth hydrograph fits to the measured water depth hydrograph on mean. 


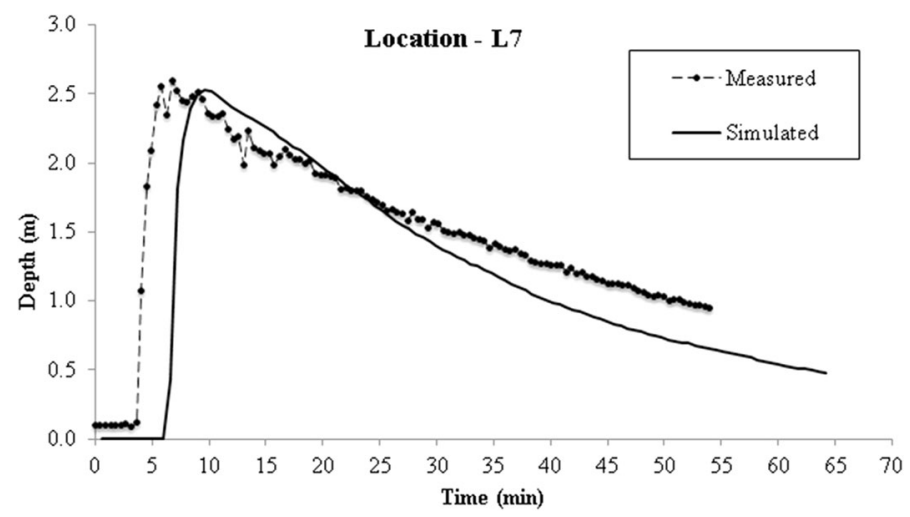

Fig. 12 Simulation of water level at L7

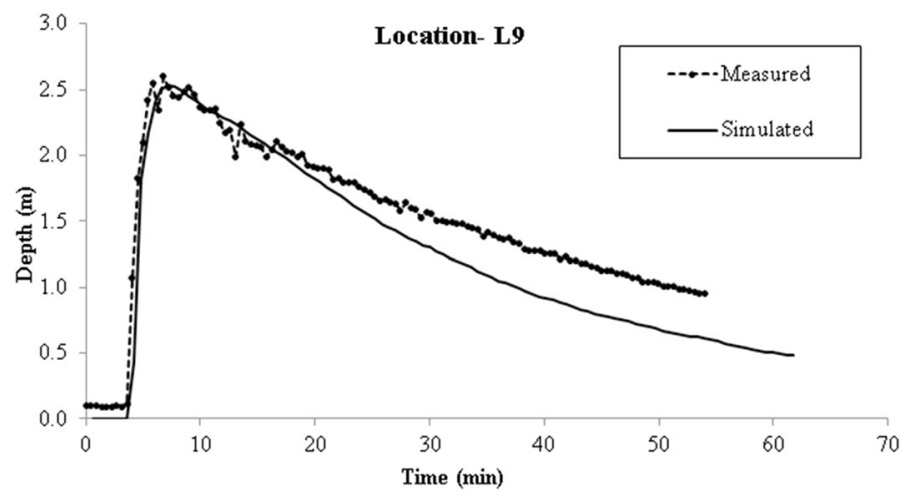

Fig. 13 Simulation of water level at L9

Table 2 Percent errors of peak flow depth and time to peak flow depth for numerical and experimental data

\begin{tabular}{lcc}
\hline Location & $\begin{array}{l}\text { Time to peak depth } \\
\text { percent }(\%) \text { error }\end{array}$ & $\begin{array}{l}\text { Peak depth percent } \\
(\%) \text { error }\end{array}$ \\
\hline L2 & 42.3 & -24.7 \\
L3 & 38.0 & 19 \\
L5 & -18.5 & 26.7 \\
L6 & 41.7 & 11.3 \\
L7 & -9.8 & 11.7 \\
L9 & 10.0 & 2.0 \\
L10 & -9.8 & 11.8 \\
L11 & 7.9 & -2.6 \\
Average & 22.3 & 13.7 \\
\hline
\end{tabular}


There is approximately 2.5 -min delay at prototype scale in L7 location (see Fig. 12) that corresponds to approximately $5 \mathrm{~s}$ in the model scale. The travel speed and flood arrival time is affected by the surface roughness in the physical model. In the physical model, the surface is paved with unfinished concrete and also there are wood blocks to model the effect of the buildings on the propagation of the flood wave. There is no direct way of numerically modeling the Manning's n coefficient for such surfaces at 1:5 distorted scale, and therefore, the Manning's n coefficient is used as the calibration parameter. During the calibration process, the peak depth and time to peak depth in measured water depth hydrographs are simulated at each measurement points. Therefore, while at some comparison points the simulated and measured results match relatively well (see location L9, Fig. 13), at some other locations the matching is not as successful (such as location 7, Fig. 12).

As summarized in Table 2, the two-dimensional numerical model simulated the laboratory experiments satisfactorily with, on the average, $22 \%$ time to peak depth and $14 \%$ peak depth errors.

Other reasons for the differences in the numerical and physical model flow depth results may be due to inadequacy of large-scale (1:5) distorted physical model in simulating the two-dimensional transient and non-uniform flow hydrodynamics in the prototype.

\section{Conclusions}

This study investigated the flood inundation due to a possible failure of Ürkmez Dam in İzmir, Turkey. Flood hydrograph downstream of the dam was modeled for a hypothetical dam failure scenario using one-dimensional hydraulic routing model HEC-RAS. The twodimensional hydraulic routing model FLO-2D was used to model the spreading of the flood wave after the flood wave exits the canyon.

The maximum flow depth, maximum flow velocity and time to maximum flow depth maps were created for the hypothetical dam failure scenario based on verified two-dimensional hydrodynamic model results. The results reveal that flow depths can reach up to $3 \mathrm{~m}$ in the residential area and in about $40 \mathrm{~min}$ after the dam-break initiates most of the residential area in Ürkmez Town will be flooded at maximum flow depth.

The authorities can use the inundation maps developed in such studies for the preparation of emergency evacuation plans as well as natural hazard assessment studies. It has the potential to be a reference for future dam-break inundation research studies and practical applications.

The two-dimensional numerical model was tested against physical model by comparing the calculated flow depth hydrographs with those measured in the distorted physical model of Ürkmez Dam at eight locations. Both peak flow depths and timing of the peak flow depths match well after calibrating the constant roughness coefficient in the numerical model. The variation in the numerical and physical model results may be associated with the variation in the representation of the topography. As the numerical model uses the actual topography at 75-m averaged horizontal resolution, physical model is constructed as cross-section transects. Therefore, the physical model topography may not represent the actual topography as precise as the numerical model does. Other reasons for the differences in the numerical and physical model flow depth results may be due to inadequacy of largescale (1:5) distorted physical model in simulating the two-dimensional transient and non- 
uniform flow hydrodynamics in the prototype and the possible measurement errors in the water depth sensors.

During the physical model tests, it is observed that the fluctuations and splashes on the water surface is most pronounced near the immediate downstream of the dam during the lifting of the dam body. 1:5 distortion in the horizontal and vertical scales also contributes to the magnitude of this noise in the measurements. The $2 \mathrm{D}$ numerical model is not capable of modeling the noise due to the splashes and disconnections in the water body, rather calculates relatively smooth varying (mean) water depths at the same location. Therefore, the numerically simulated water depth hydrograph fits to the measured water depth hydrograph on mean.

The travel speed and flood arrival time is affected by the surface roughness in the physical model. In the physical model, the surface is paved with unfinished concrete and also there are wood blocks to model the effect of the buildings on the propagation of the flood wave. There is no direct way of numerically modeling the Manning's n coefficient for such surface at 1:5 distorted scale, and therefore, the Manning's n coefficient is used as the calibration parameter. During the calibration process, the peak depth and time to peak depth in measured water depth hydrographs are simulated at each measurement points. Therefore, while at some comparison points the simulated and measured results match relatively well, at some other locations, the matching is not as successful.

Acknowledgments This study was funded by research grant from the Turkish Science Foundation (TÜBITAK) through Project No: 110M240.

\section{References}

Alcrudo F, Mulet J (2007) Description of the Tous Dam break case study (Spain). J. Hydrau Res 45:45-58 Bellos C, Hrissanthou V (1998) Numerical simulation of sediment transport following a dam break. Water Resour Manag 12(6):397-407

Bellos V, Tsakiris G (2015) Comparing various methods of building representation for 2D flood modelling in built-up areas. Water Resour Manag 29:379-397

Bosa S, Petti M (2013) Overtopped the Vajont Dam in 1963. Water Resour Manag 27(6):1763-1779

Bozkus Z (2003) Pre-event failure analysis of Kestel Dam for disaster management. Int J Phys Eng Sci 53:58-64

Bozkus, Z. (2009). Failure analysis for Cinarcik Dam. IV. National Water Engineering Symposium, 6-10 July 2009, İstanbul, Turkey. pp. 89-98. (in Turkish)

Bozkus Z, Bag F (2011) Artificial failure analysis of Cinarcik Dam. Tek Derg 22:5675-5688

Bozkus Z, Guner AI (2001) Pre-event dam failure analyses for emergence management. Turk J Eng Environ 25:627-641

Brufau P, Vazquez-Cendon ME, Garcia-Navarro P (2002) A numerical model for flooding and drying of irregular domains. Int J Numer Methods Fluids 39:247-275

Cagatay H, Kocaman S (2008) Experimental study of tailwater level effects on dam break flood wave propagation. In: Altinakar MS, Kokpinar MA, Aydin I, Kirkgoz S (eds) River flow 2008, vol 1, pp. 635-644. Proceedings international conference on Fluvial Hydraulics, Izmir, Turkey, 3-5 September 2008

DSI (1979) Izmir Gumussu-Urkmez project planing report. State water works, Division of project and planing, Ankara, Turkey

FLO-2D (2009a) FLO-2D users manual documentation. http://www.flo-2dforum.com/topic/flo-2ddocumentation

FLO-2D (2009b) FLO-2D grid developers system GDS user manual. http://www.flo-2d.com/wp-content/ uploads/2013/11/Pocket-GUIDE-PRO.pdf

Froehlich DC (2008) Embankment dam breach parameters and their uncertainities. J Hydraul Eng 134(12):1708-1721 
GEI Consultants Inc (2014) Hayden reservoir Dam and Davis No. 1 Dam breach inundation mapping report. Denver Co, USA

Guney MS, Tayfur G, Bombar G, Bayram D (2013) Experimental investigation of flood propagation due to trapezoidal breach in the distorted physical model of Urkmez Dam. International Perspectives on Water and Environment, IPWE2013, Izmir

Guney MS, Tayfur G, Bombar G, Elci S (2014) Distorted physical model to study sudden partial dam break flows in an urban area. J Hydraul Eng 140(11):05014006

Haltas I, Odell R (2013) Two dimensional modeling and gis integrated mapping of the dam-break inundation, a case study: Lake Isabella Dam. In: Proceedings of 6th international perspective on water resources \& the environment, İzmir, Turkey

Kocaman S, Çağatay H (2009) Baraj yıkılması akımının analitik ve deneysel karşılaştırılması. IV. Ulusal Su Mühendisliği Sempozyumu, Orhantepe, İstanbul, pp 77-87 (in Turkish)

Li L, Cargnelutti M, Mosca C (1991) Dam-break flood forecasting in Piemonte region, northwest Italy. Water Resour Manag 5(3-4):261-270

Macchione F (2008) Model for predicting floods due to earthen dam breaching. I. formulation and evaluation. J. Hydraul Eng 134(12):1688-1696

Mahdizadeh H, Stansby PK, Rogers BD (2012) Flood wave modeling based on a two-dimensional modified wave propagation algorithm coupled to a full-pipe network solver. J Hydraul Eng 138(3):247-259

Minussi RB, Maciel GF (2008) Dam break-problem-complete solution and shallow water approximation comparison. In: Altinakar MS, Kokpinar MA, Aydin I, Kirkgoz S (eds) River flow 2008, vol 1, pp. 619-626. Proceedings international conference on Fluvial Hydraulics, Izmir, Turkey, 3-5 September 2008

Moramarco T, Barbetta S, Pandolfo C, Tarpanelli A, Berni N, Morbidelli R (2014) The spillway collapse of the Montedoglio damon the Tiber River (central Italy):data collection and event analysis. J Hydrol Eng 19(6):1264-1270

Morris MW, Hassan MAAM, Samuels PG, Ghataora GS (2008) Development of the HR BREACH model for predicting breach growth through flood embankments and embarkment dams. In: Altinakar MS, Kokpınar MA, Aydin I, Cokgor S, Kırkgoz S (eds) River flow 2008, vol 1, pp. 679-688. Proceedings international conference on Fluvial Hydraulics, Izmir, Turkey, 3-5 September 2008

Palumbo A, Soares-Frazao S, Goutiere L, Pianese D, Zech Y (2008) Dam-break flow on mobile bed in a channel with a sudden enlargement. In: Altinakar MS, Kokpinar MA, Aydin I, Kirkgoz S (eds) River flow 2008, vol 1, pp. 645-654. Proceedings international conference on Fluvial Hydraulics, Izmir, Turkey, 3-5 September 2008

Petaccia G, Natale L, Savi F (2008) Simulation of the Sella Zerbino catastrophic dam break. In: Altinakar MS, Kokpinar MA, Aydin I, Kirkgoz S (eds) River flow 2008, vol 1, pp. 601-608. Proceedings international conference on Fluvial Hydraulics, Izmir, Turkey, 3-5 September 2008

Pilotti M, Maranzoni A, Tomirotti M, Valerio G (2011) 1923 Gleno Dam break: case study and numerical modeling. J Hydraul Eng 137(4):480-492

Pinho J, Ferreira R, Vieira L, Schwanenberg D (2015) Comparison between two hydrodynamic models for flooding simulations at river Lima basin. Water Resour Manag 29:431-444

Qi H, Altinakar M (2012) GIS-based decision support system for dam break flood management under uncertainty with two-dimensional numerical simulations. J Water Resour Plann Manag 138(4):334341

Singh J, Altinakar MS, Ding Y (2011) Two-dimensional numerical modeling of dam-break flows over natural terrain using a central explicit scheme. Adv Water Resour 34:1366-1375

Tsakiris G, Spilliotis M (2013) Dam-breach hydrograph modelling: an innovative semi-analytical approach. Water Resour Manag 27(6):1751-1762

USACE (2010) HEC-RAS river analysis system. Hydraulic reference manual. Version 4.1. U.S. Army Corps of Engineers, Hydrologic Engineering Center. http://www.hec.usace.army.mil/software/hec-ras/ documentation/HEC-RAS_4.1_Reference_Manual.pdf

USACE (2014) Using HEC-RAS for dam break studies. TD-39. U.S. Army Coprs of Engineers, Hydrologic Engineering Center. http://www.hec.usace.army.mil/publications/TrainingDocuments/TD-39.pdf

Vasquez JA, Leal JGB (2006) Two-dimensional dam-break simulation over movable beds with an unstructured mesh. In: Ferreira RML, Alves ECTL, Leal JGAB, Cardoso AH (eds) Riverflow 2006, vol I, Taylor \& Francis, Portugal, pp 1483-1491. ISBN:0-415-40815-6

Wikipedia (2015). http://en.wikipedia.org/wiki/Dam_failure, http://naturalhazards.ntua.gr (the Centre for the Assessment of Natural Hazards and Proactive Planning (CANAH) of the National Technical University of Athens)

Yanmaz AM, Beşer MR (2005) On the reliability-based safety analysis of the Porsuk Dam. Turk J Eng Environ Sci 29(5):309-320 
Yanmaz AM, Seçkiner G, Özaydın V (2001) A method for optimum layout design of concrete gravity dams. Water Eng Res Int J Korea Water Res As 2(4):199-207

Ying X, Jorgeson J, Wanf SS (2009) Modeling dam-break flows using finite volume method on unstructured grid. Eng Appl Computat Fluid Mech 3(2):184-194 